\title{
Applying the war historical re-enactment method in teaching historical painting
}

\author{
Yevgeny Suzdaltsev ${ }^{1, *}$, Peter Khromenkov ${ }^{1}$, Pavel Chistov ${ }^{1}$ and Irina Pavelyeva ${ }^{1}$ \\ ${ }^{1}$ Moscow Region State University, 10A, Radio str., 105005, Moscow, Russia
}

\begin{abstract}
Being an artist is not enough to make a piece of historical art. This requires a study, the deliverables of which allow creating a scientifically reliable composition. To put it otherwise, an artwork brought into existence in such a way can be created on an interdisciplinary basis, and it is not until then that it becomes educational. A study used in the educational process considerably increases the degree of professional competence of students. The authors of this article, being professors at the Fine Arts and Folk Crafts Department, Moscow Region State University, have employed a range of research methods as the basic ones. These include war historical re-enactment, case review of its research and organization in modern social and cultural settings, modeling and forecasting deliverables of students ${ }^{6}$ artistic activities when creating historical paintings, and the method of expert evaluation. In order to trial war historical re-enactment as an academic research method together with the Department's students, art and research project "Neuchatel's Battalion at the Battle of Wagram" has been launched across the curriculum. The project incorporates stages of joint research and artistic work of academicians and students. During the project, a mechanism of interknowledge interaction is formed in the minds of students, which allows students to acquire historical knowledge about the Neuchatel battalion, Battle of Wagram, uniforms worn during the Napoleonic Wars, and the work of battle painters. Based on the above, the students acquire metadisciplinary skills they employ to create themed art in terms of traditional battle paintings by Alexander Averyanov, Peter von Hess, and Louis-Francois Lejeune. We have summarized the experience of employing the war historical re-enactment method in teaching students historical painting. It is reflected in the study guide students use to study military garments worn in the early 19th century and create themed works of art. Its contents are recommended for both teachers and students studying art to create student artworks consistent with traditional battle paintings.
\end{abstract}

\footnotetext{
*Corresponding author: moiseev_arthouse@mail.ru
} 


\section{Introduction}

In the history of each country, there are heroic pages that artists seek to depict in their works. Unfortunately, many of them, as people of art, forget to fully show the everyday routine and cultural life of the period depicted, believing that recapturing a historical event and expressing their personal attitude through artistic means is quite enough. As a result of authors" disregard for details, ignoring the sequence of events, viewers begin at first to doubt what they see and then to question the actual historical fact.

Thus, artists, if they ignore all the routine and cultural life details and features of the period depicted, expose their works to the risk of losing their artistic value and, inevitably, becoming defective in terms of bringing up real citizens and patriots of their homeland.

Solving the problem of creating a scientifically sound artistic composition requires a student, who creates a historical work, to search for the necessary materials on the depicted events at the interdisciplinary level, update their knowledge on historical garments, weapons, etiquette, and everyday life characteristic of the era shown in their work. The authors of this article, artists themselves and teachers at the Fine Arts and Folk Crafts Department of the Moscow Region State University (MRSU), propose to follow the war historical re-enactment method to solve the above problem. This method is widely used by participants of the war historical re-enactment movement in their research work.

Yevgeny Suzdaltsev, university professor and one of the authors of this article, as an active participant of the historical re-enactment movement and a member of the Russian Public Movement "Russian Historical Re-Enactment Clubs." Professor Suzdaltsev studies the Napoleonic wars and runs the MRSU-based themed club, members of which recreate the lives of soldiers and officers of the Neuchatel battalion both in bivouacs and in action and take part in festivals held on the battlefields of Waterloo, Austerlitz, Jena, Borodino, etc. (Figure 1).

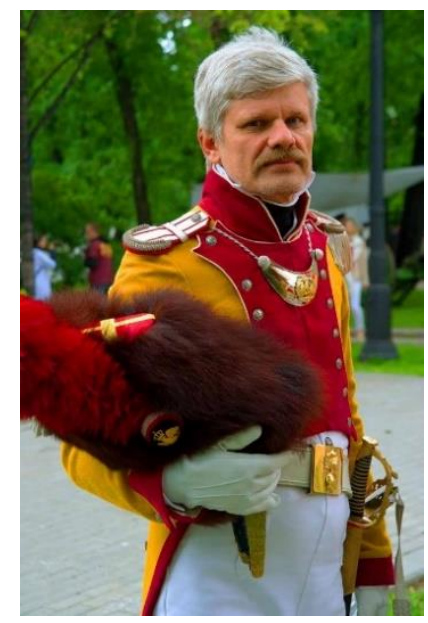

Fig. 1. Yevgeny Suzdaltsev, one of the art project's authors, MRSU Professor, Head of the Neuchatel Battalion War Historical Club.

Speaking about the war historical re-enactment method being used, it is necessary to define a relatively young social phenomenon, which is currently represented by the war historical re-enactment movement operating under the motto: "Through the hardships of past wars to peace." The authors define the movement as a set of activities aimed at studying and modeling events from the history of human wars, based on physical, visual, and written sources. War historical re-enactment, with its scientific basis laid down by the historians of the early 20th century who collaborated with the Annales. Histoire. Sciences Sociales 
magazine, has become the cornerstone of a new approach to historical research they developed. It was reflected in a binary field of knowledge, historical anthropology. As Aron Gurevich, Russian historian, puts it, this method ensured the emergence of a "humancentered" movement [1]. This very approach, which pays attention to a human being caught in the eye of the historical "whirlwind," is what re-enactment is based on. In addition, representatives of the "Annales School" were among the first to highlight the role of artworks as one of the sources of scientific knowledge of history.

This problem is primarily researched by military re-enactors using interdisciplinary knowledge in such fields as history, political science, military education, psychology, and sociology. To ensure full and holistic recreation of the appearance of people from the past periods being re-enacted, they introduce previously unknown sources into science, re-create and use as intended full-scale items of material culture best resembling historical samples of the correspondent periods. Russia has recognized the researches of the most renowned scientists among military re-enactors: Klim Zhukov's work on the Middle Ages war history; Boris Megorsky's study of the Russian-Swedish War of 1700-1721; Alexander Valkovich, Oleg Sokolov, Ilya Ulyanov's researches on Napoleonic war army arrangement and structure [2, 3, 4, 5]. Returning to art, Alexander Kibovsky, military re-enactor and currently the Minister of Culture of the Moscow Government, has developed a historical and subject-based method of attributing portrait paintings, which gave back their original identities back to over 500 forgotten heroes whose portraits were painted by famous Russian painters of the 18th century and the first half of 19th century [6]. At the same time, there are few scientific papers on the professional training of art department students. In this regard, based on research deliverables and the use of the war historical re-enactment method in art education, we have set our purpose as follows: to prove the effectiveness of teaching students to create scientifically sound historical compositions dedicated to the heroic past of our homeland. In line with the purpose of this study, its main objectives are as follows: identifying settings necessary to teach students the basics of historical painting, determining the optimal combination of historical and artistic aspects in educational and cognitive activities that reflect the essence of the war historical re-enactment method, and building up a phased sequence to follow when working on historically themed artistic compositions.

\section{Materials and Methods}

War historical re-enactment as a method of scientific and educational research; since 2019, it has been used by the Fine Arts and Folk Crafts Department as a component of the artistic and educational technology employed to achieve the following goal: teaching students to create historical paintings.

During the preliminary research, components of the war historical re-enactment method were determined using structural and factor analysis methods. It was established that its structure includes:

1. methods of analyzing physical, visual, and documentary sources, which involves mandatory benchmarking of information obtained from various sources to achieve the most complete re-enactment of historical events;

2. methods of recreating full-scale items of material culture to resemble historical samples of the period re-enacted as much as possible;

3. methods of recreating human behavior when modeling a specific historical period with due consideration given to the social status of those being depicted.

Using this method, the Department started working on an art project aimed at translating Napoleonic war events into a historical composition: "Neuchatel's Battalion at the Battle of Wagram." This battle of the Franco-Austrian War of 1809 has already been 
reflected in the works of such famous battle painters, such as Carle Vernet and Jacques Swebach (Battle of Wagram), Horace Vernet (Battle of Wagram on July 6, 1809), January Suchodolski (Polish Uhlans' Bivouac near Wagram), Albrecht Adam (After the Battle of Wagram), Wojciech Kossak (Attack at the Battle of Wagram), Jean Baptiste Edouard Detaille (General Lasalle Leads the Attack at Wagram on June 6, in the Afternoon, before Being Killed), Joseph Louis Hippolyte Bellange (Napoleon at Wagram). However, none of these painters depicted the heroic efforts of the Neuchatel Battalion to defend the French crossings between the Island of Lobau and the right bank of the Danube from Austrian attacks. This allowed maintaining a steady supply to Napoleon's troops, which led to his victory in the battle.

Given that this project aims at creating a work of art, the following research methods of artistic activities were employed, covered by Alexander Novikov, academician of the Russian Academy of Education, in his work "Methodology of Artistic Activities" [7]:

1. artistic search methods;

2. methods of artwork creation;

3. methods of artwork presentation;

4. methods artwork reinterpretation.

The work on the art project began by establishing Stanislav Lomov's Historical Painting Workshop within the Department lead by Pavel Chistov, Ph.D. (Mr. Lomov is a member of the Russian Academy of Arts). MRSU professors, including Alexey Temnikov, renowned artist and war re-enactor, joined the Workshop to help organize the work. Alexander Averyanov [8], whose paintings depict significant events of the Napoleonic wars, was invited in an advisory capacity. Students to join the Workshop were selected based on their own will and skills. The learning process was guided by such didactic principles of higher education as science principle; interdisciplinarity principle; the principle of scientific knowledge consistency and relative completeness; the principle of interpreting historical facts; phenomena, and processes; multi-level learning, continuity, and consistency principle; educative learning principle. In addition, when working on the project, we relied on the key theoretical provisions of the Russian classical art education, whose prominent representatives include Nikolay Rostovtsev and Vladimir Kuzin, scientists and professors who taught art disciplines at MRSU [9]. These provisions provided the basis for the Workshop's art project phased plan (Table 1). The plan includes the following phases: 
Table 1. Long-term art project work plan "'Neuchatel's Battalion at the Battle of Wagram"'.

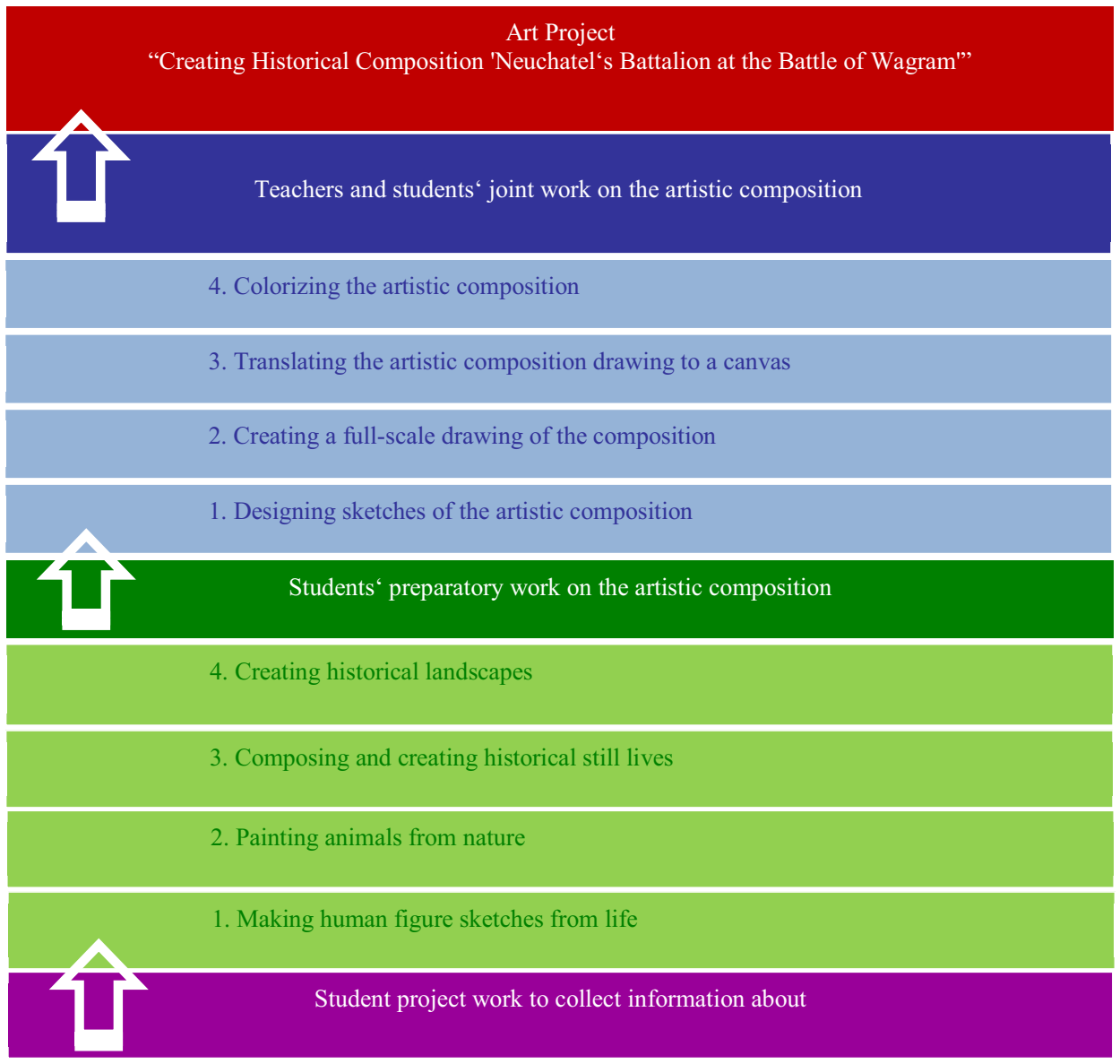

the army service uniform worn during the FrancoAustrian War of 1809

4. Research project

"Army Service Uniform of Neuchatel's Battalion"

3. Research project

"Army Service Uniform of the Austrian Empire"

\section{Research project}

"Army Service Uniform of the French Empire"

1. Research project

"Army Service Uniform of the Duchy of Baden" based on paintings depicting the Napoleonic war events

4. Research project

"Louis-Francois Lejeune"s Creative Legacy"

3. Research project

"Alexander Averyanov‘s Creative Legacy"

2. Research project

"Peter von Hess's Creative Legacy"

1. Research project

"Richard Knotel's Creative Legacy"

Being an integral part of the war historical re-enaction method, analysis of physical, visual, and documentary sources was frequently used during Phase 1 work on the art project 
involving a range of students' learning activities and the professional guidance from their mentors:

- teachers and students' joint work to collect information about the events of the FrancoAustrian War of 1809, stages of the Battle of Wagram of July 5-6, 1809, and participation of Neuchatel's Battalion, using a variety of sources;

- insights into the history of shaping and structuring Neuchatel's Battalion and its battle route between 1807 and 1814;

- insights into the tactics of infantry armies of the Napoleonic wars, which will allow authors of artistic compositions to picture to themselves the way military units and individual soldiers behaved in battles, on a march, and at bivouacs.

During Phase 1, the materials listed in the plan were collected, the project participants visited the Day of Borodino military and historical festival, where they made sketches of people, horses, munitions, and soldiers' personal belongings of the early 19th century, getting acquainted with the methods of recreating full-scale material culture articles best resembling historical samples of the period being re-enacted.

Phase 2 consisted of two stages, one of them involving an analysis of visual and documentary sources through organizing students' project work on studying the army service uniform worn during the French-Austrian War of 1809 and the visual reconstruction of the ranks representing Neuchatel's Battalion (Figure 2) based on uniform-depicting folders by Henri Boissillier, French artist of the early 20th century. The other stage included analyzing legacies of artists who retraced the events of the Napoleonic wars in terms of the traditional battle painting (Alexander Averyanov, Peter von Hess, LouisFrancois Lejeune).
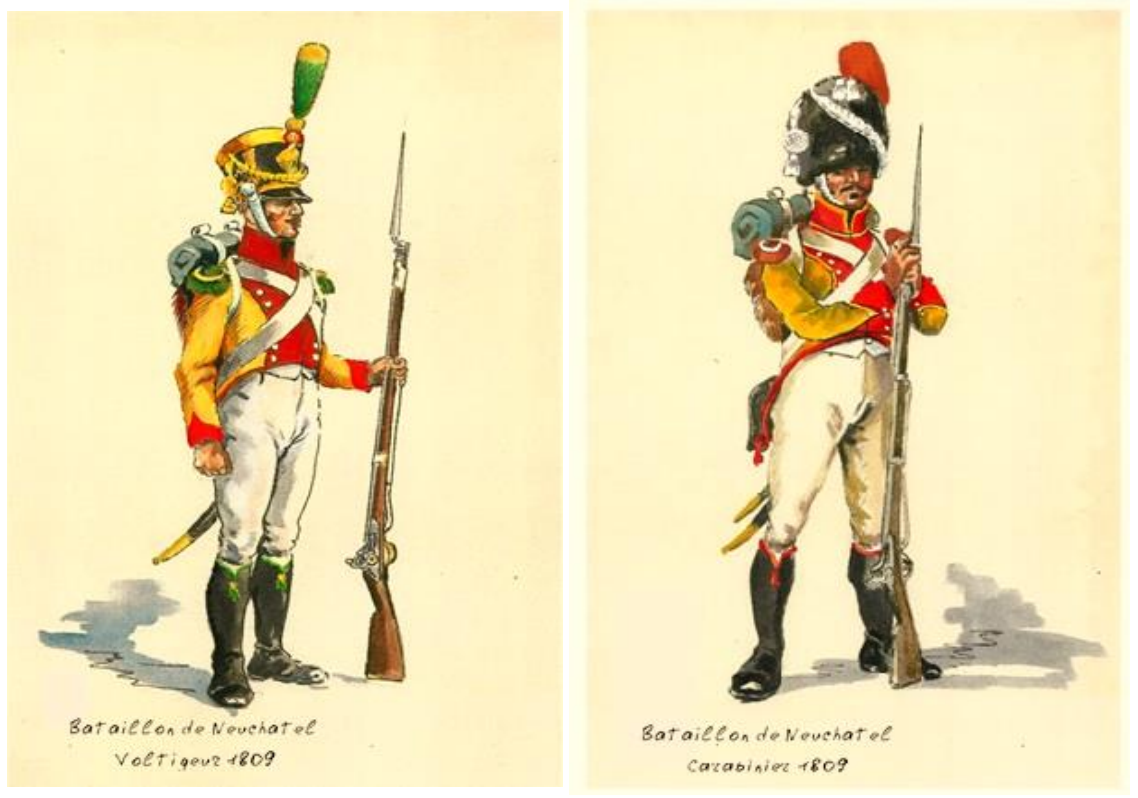

Fig. 2. Graphic reconstructions of the "Service Uniform of Neuchatel's Battalion Worn in1809" by MRSU students in the style of drawings by Henri Boissillier.

The students' research work was featured by the search for and generalization of physical (exhibits from Paris- and Vienna-based Army Museums), visual (drawings by Pierre Martinet, Richard Knottel, Rigaud, Pavel Alekhine, Frederic Beriot), and documentary sources on Neuchatel's Battalion (Alan Pajard, Francois-Guy Urtulle, Alfred Guy) [10-15]. This work consisted not only of supposing what the ranks of Neuchatel's Battalion, soldiers 
and officers of the Austrian and French Armies might have looked like in the summer of 1809 , but also of searching for information about the army service uniform the Grand Duchy of Baden in 1809, whose Infantry Regiment 3, according to Oliver Michael's Handbook [16], from 11 a.m. to 12 a.m. on July 6, 1809, together with Neuchatel's Battalion, defended the river crossings, maintaining a steady supply line to the French Army.

Based on the methods of analyzing physical, visual, and documentary sources, the research projects provided for in the plan were implemented in Phase 2. To help students perform the work better,

- a study guide on the army service uniform worn during the Napoleonic war era "Empire-Styled Army Service Uniform" was developed by the Department's professors for art department students. The Grand Army Infantry on the example of Neuchatel's Battalion [17];

- a series of lectures on uniformology as an auxiliary historical discipline was held to provide insights into the legacy of Napoleonic war era artists who depicted uniforms;

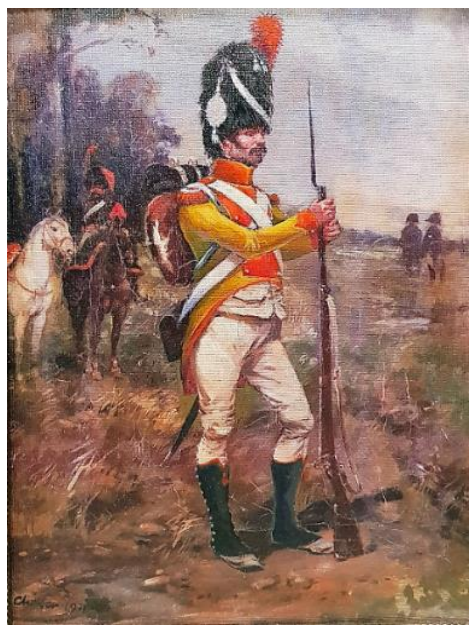

a

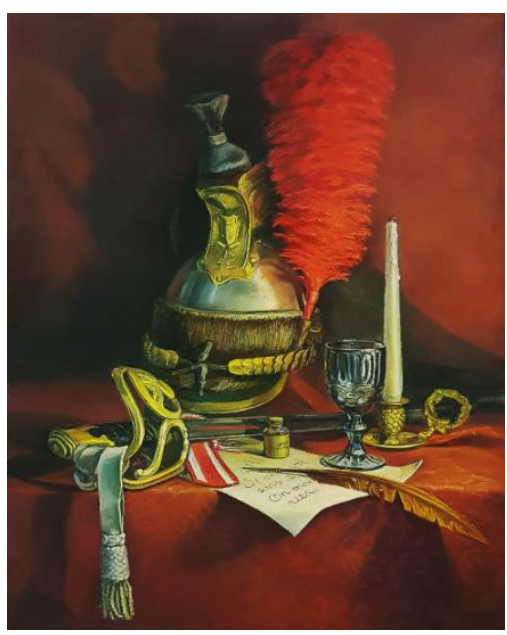

b

Fig. 3. a - "Carabiniere of Neuchatel's Battalion in the Picket Line Defending the Emperor" (oil on canvas). Work by Yevgeny Suzdaltsev, MRSU Professor (David William Paget's private collection), b - "Still life of the Napoleonic War Era" (pastel on cardboard). Work by Nataliya Murashkina, MRSU student (MRSU collection).

- an exhibition of historically themed works created by academicians of the MRSU Fine Arts Department was held (Figure 3a); plots of historical paintings created by LouisFrancois Lejeune, battle artist, were compared with what really took place across the Napoleonic battlefields. Attention was drawn to the fact that the artist himself was a Brigadier General of Napoleon's army and personally fought for Napoleon, which he conveyed in great detail in his works.

During Phase 3 of the art project, students' preparatory work was organized, which resulted in creating landscape drawings of the Wagram battlefield based on the 20thcentury drawings, engravings, and battle maps. Still lives were composed of items recreated from the Napoleonic era material culture and put onto canvas (Figure $3 b$ ). These items were created by the hands of Moscow-based war historic re-enactors, such as Denis Shayen, Dmitry Pashkov, Yevgeny Suzdaltsev, Chingis Ibragimov, and Valeriya Almayeva, and best resemble museum items. Given the importance of the still life genre in the formation of artistic skills, Stanislav Lomov, renowned Russian artist, said: "Still life painting is an important means of adjusting and checking the artist's vision and working 'language.' It is 
no accident that many artists, before taking up large-scale genre paintings, create still lives" [18].

Also, drawings of animals and sketches of human figures in motion were created from life using such methods of war historical re-enactment as modeling human behavior by recreating a specific historical period with due consideration to the social status of those being depicted. Drawings and sketches were made by students from life during the war historical re-enactment festivals held at the battlefields of the Patriotic War of 1812 near Borodino, Maloyaroslavets (Figure 4) and Europe"s largest "Times and Epochs" Historical Festival held annually in Moscow's streets. Military re-enactors and festival participants who know how to wear and how to move while wearing army service uniforms of the Napoleonic war era were involved as models for the drawings, which will later allow, based on the drawings and sketches, to accurately convey the actions of the depicted figures into the artistic composition.
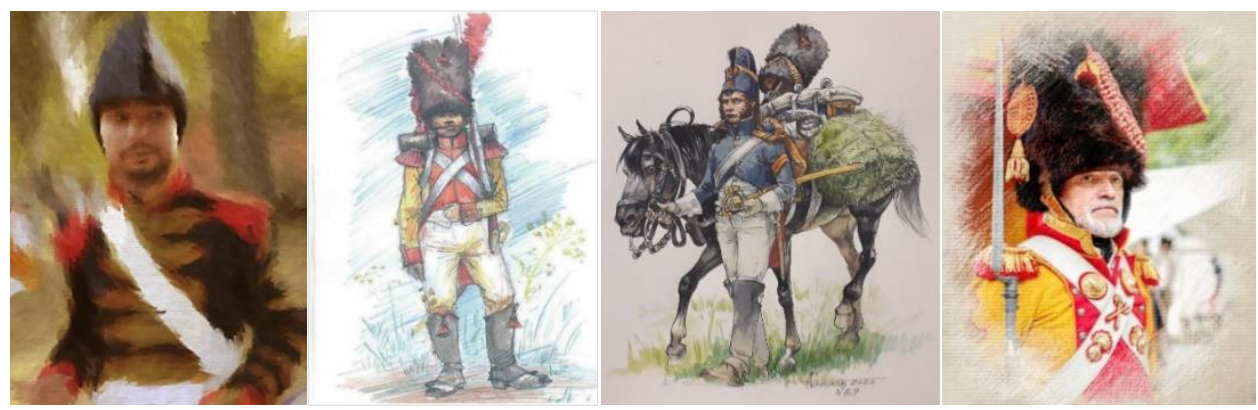

Fig. 4. The drawings and sketches made from life by MRSU students and professors (Alexey Temnikov) using a variety of materials (oil paint on canvas; colored pencils on paper; ink, pen, and pastel on cardboard) "Figures of people wearing the army service uniforms of Neuchatel's Battalion and the Cavalry Regiment of the Imperial Guard".

Employing the war historical re-enactment methods when modeling the behavior of a person depicting a specific historical period with due consideration to the social status of those being depicted during Phase 3, the following workshops were held to enhance the performance of students:

- drawing horses in motion, supervised by Alexey Temnikov, artist and war re-enactor;

- making sketches of human figures in motion, supervised by Alexey Temnikov, artist and war re-enactor.

During the final phase of the art project, the following methods of artwork creation were used: developing sketches of artistic composition, painting full-scale compositions, transferring images of artistic compositions to canvas, creating color artistic compositions. This phase mainly consisted of professors and students' joint work on artistic compositions.

When making sketches of the artistic composition, many of the project participants proposed a number of compositional solutions suitable for the historical plot. However, it was decided to create the composition in terms of the traditional battle painting of the 19th century represented by such maestros as Lejeune and von Hess, with an accurate depiction of landscapes and historical events of the given time period (11 to 12 a.m. July 6, 1809, the right bank of the Danube opposite the Island of Lobau), (Figure 5). In the course of the work, preparatory $b \& w$ and color sketches of the composition were made. 

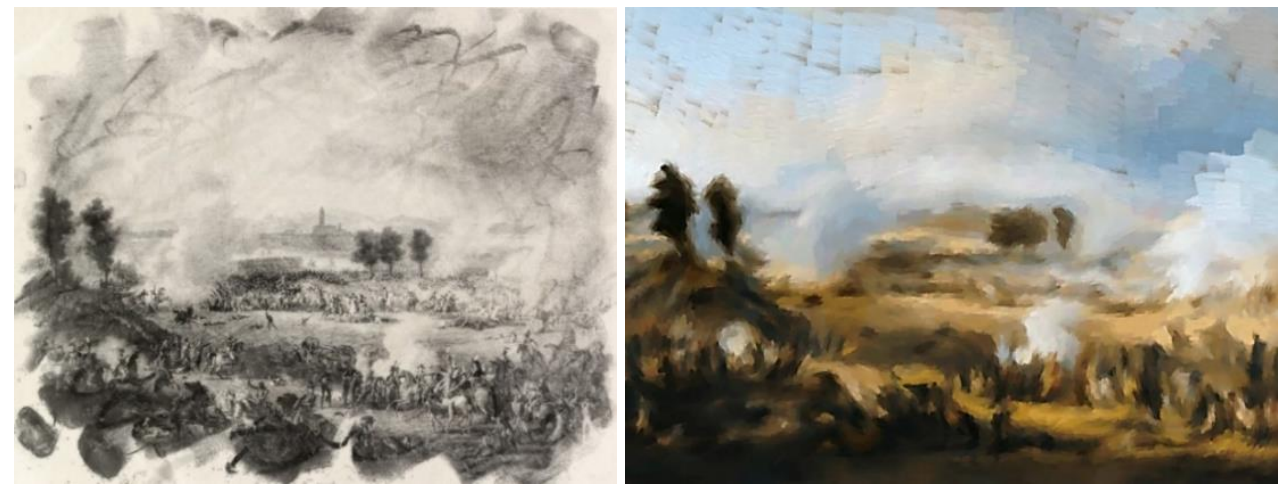

Fig. 5. Preparatory b\&w and color sketches of the artistic composition.

Alexey Temnikov suggested adding dynamics to the composition to reflect the dramatic scenes of the Battle of Wagram 1809 (Figure 6): breaking of the Austrian troops through to the Danube crossing overrunning the French defenses, persistent defense of the Neuchatel and Baden's crossings, desperate attacks of the French Cuirassiers and preparations for the celebrated attack of the McDonald convoy that determined the battle was won by the French by overthrowing Austrian Archduke Charles's central flank.
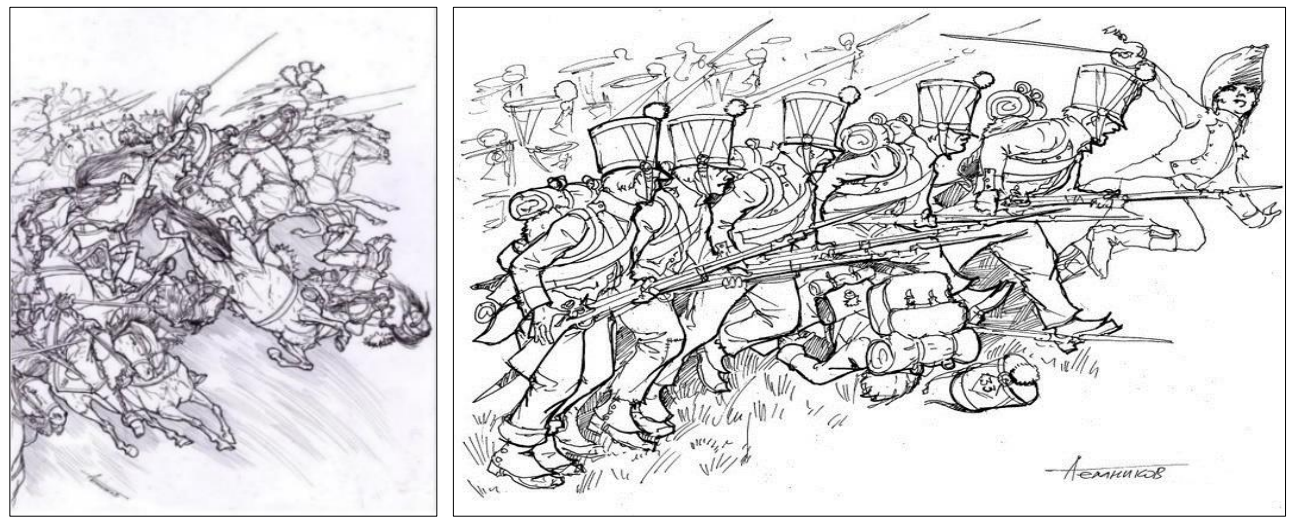

Fig. 6. Sketches of the art composition fragments made by Alexey Temnikov "Battle scenes of the French-Austrian War of 1809”.

Given that less than a year has passed since the project began, the final phase work is currently underway on making a full-scale drawing of the composition, followed by transferring the artistic composition drawing to canvas and creating its version in color.

\section{Results}

Summing up what is ready at the current phase of the art project "Neuchatel's Battalion at the Battle of Wagram," we can say that the war historical re-enactment method includes the following: methods for analyzing physical, visual, and documentary sources, which involves comparing and supplementing information obtained from various sources. Thanks to this, a mechanism of knowledge interaction can be formed along with developing the holistic knowledge necessary for the most complete re-enactment of historical events. The methods for recreating human behavior employed in modeling a specific historical period 
with consideration to the social status of those being depicted help create scientifically sound historical artworks. The use of these methods is effective in the following cases:

- implementation of the necessary settings, such as those the MRSU Fine Arts Department has successfully created (that is, the establishment of the Historical Painting Workshop to teach students interested in mastering the basics of the battle genre);

- sequential performance of the phased work on artistic compositions using such artistic methods as artistic search methods, methods of artwork creation, methods of artwork presentation, methods artwork reinterpretation;

- conducting research on the topic under study is mandatory on both parts: historical and artistic;

- creating completed artworks (still lives from items that are expressive of a given era, historical landscapes) and preparatory works (drawings, sketches) as part of the preparation for the final phase of creating historical artistic compositions.

For clarity, we offer a brief comparative analysis revealing the effectiveness of using the war historical re-enactment in art education. The experimental group includes students of the Department attending the Historical Painting Workshop and actively using this method, while the control groups include students studying painting and pedagogics without using this method.

Comparison indicators meet the criteria for evaluating knowledge, skills, and abilities of students of art departments (Table 2):

Table 2. Efficiency comparison of using the war historical re-enactment method when creating historical artistic compositions.

\begin{tabular}{|c|c|c|c|}
\hline \multirow[b]{2}{*}{$\begin{array}{l}\text { Analysis of students' } \\
\text { actions when creating } \\
\text { artistic compositions }\end{array}$} & \multicolumn{3}{|c|}{$\begin{array}{c}\text { Student groups creating pieces of art in the genre of historical } \\
\text { painting }\end{array}$} \\
\hline & $\begin{array}{l}\text { experimental group of } \\
\text { students from those } \\
\text { attending the } \\
\text { Historical Painting } \\
\text { Workshop }\end{array}$ & $\begin{array}{l}\text { control group } \\
\text { (painting students) }\end{array}$ & $\begin{array}{l}\text { control group } \\
\text { (pedagogics } \\
\text { students) }\end{array}$ \\
\hline $\begin{array}{l}\text { accuracy of the } \\
\text { representation of a } \\
\text { historical event in the } \\
\text { composition, based on } \\
\text { the study of physical, } \\
\text { visual, and } \\
\text { documentary sources }\end{array}$ & $72.4 \%$ & $28.5 \%$ & $26.2 \%$ \\
\hline $\begin{array}{l}\text { conveying human } \\
\text { figures, garment } \\
\text { features characteristic } \\
\text { of a given historical } \\
\text { period into preliminary } \\
\text { drawings and sketches }\end{array}$ & $81.8 \%$ & $12.3 \%$ & $10.5 \%$ \\
\hline $\begin{array}{l}\text { ability to depict those } \\
\text { items from nature and } \\
\text { imagination that best } \\
\text { resemble historical } \\
\text { samples of the period } \\
\text { being re-enacted }\end{array}$ & $92.6 \%$ & $74.1 \%$ & $58.8 \%$ \\
\hline $\begin{array}{l}\text { conveying the } \\
\text { movements of those } \\
\text { being depicted in } \\
\text { accordance with a given } \\
\text { historical period }\end{array}$ & $64.2 \%$ & $8.6 \%$ & $8.1 \%$ \\
\hline
\end{tabular}


sequential creation of artistic compositions

$92.3 \%$

$90.2 \%$

$86.2 \%$

This analysis shows that, with almost identical artistic training programs at the Department (which involve the sequential pattern of creating artistic compositions, the to depict items from nature and using imagination, which articles best resemble historical samples of the era being re-enacted), students of the experimental group, when assessed by the criteria associated with using the war historical re-enactment method, have shown results significantly superior to those of the control groups. This gives us the right to start talking about the effectiveness of using the method in art education.

\section{Discussion}

MRSU's passion for war historical re-enactment and the work of the MRSU-hosted theme club, whose members study the history and re-enact the lives of soldiers and officers of Neuchatel's Battalion of 1807-1814 using the war historical re-enactment method in their research, have led professors of the Fine Arts and Folk Arts Department to the idea of establishing Historical Painting Workshop, where teachers taught students to create historical pieces of art. It was planned that the artworks created using the war historical reenactment method would be scientifically reliable and reflect significant events from human history. Another purpose of using this method was to develop students' professional knowledge and skills. When creating historical pieces, the traditional method, i.e. the artistic activity method, was also used. This approach allowed expecting artistic tasks to be implemented in artworks.

The first project at the Department to use the war historical re-enactment method was art project "Neuchatel's Battalion at the Battle of Wagram," intended for the Russian community of Neuchatel (Switzerland). Throughout the project, a long-term plan for creating a historical composition was tested, whose effectiveness was confirmed during its three-phase implementation. The plan involved a comprehensive and consistent approach to meeting the goal, that is, creating a historical artwork. According to the plan, the intermediate phases of the project encompassed creating a number of completed artistic compositions in varied techniques, which have become an integral part of the project (sketches, graphic reconstructions, historical still lives, and landscapes).

The successful completion of the project's final stage, that is, creating a battle picture, confirms that arranging the artistic training process through using the historical genre, which is of great importance in the training, self-development, and patriotic education of young people, was the right decision.

\section{Conclusions}

The method of war historical re-enactment seamlessly intertwines with the traditional method of artistic activity used in the creation of artworks. With this in mind, the Department plans to continue creating scientifically sound historical compositions that have educational and developmental significance for both students and visitors to exhibitions where the above historical artworks are displayed. Combining the methods of war historical re-enactment and the artistic activity makes it possible to improve the professional skills of teachers and students of the Historical Painting Workshop of the MRSU Fine Arts and Folk Crafts Department.

The analysis of the work done under the long-term plan of art project "Neuchatel's Battalion at the Battle of Wagram" suggests that our hypothesis that the method of war historical re-enactment is a productive way of implementing such projects has been 
confirmed. This method can be recommended for use in the educational process at the History Department in research work to enrich its theoretical part through providing practice.

\section{Acknowledgments}

In conclusion, on behalf of the entire project team, the authors would like to thank Veronika Zapalatskaya, Principal of the Moscow Region State University, for supporting the project within the University, Mikhail Shmayevich, Executive Director of the Russian Public Movement "Russian Historical Re-Enactment Clubs," for supporting the participation of the MRSU-hosted War Historical Re-Enactment Club "Neuchatel's Battalion" in theme festivals, and David Paget, one of the leaders of the re-enactment movement in Europe, for his invitations to European celebrations held in commemoration of the Napoleonic wars era events. Thanks to their support, we have succeeded in creating favorable settings for using the method of war historical re-enactment in the art training of students, which significantly increases its quality.

\section{References}

1. A.Y. Gurevich, Bulletin of the USSR Academy of Sciences 7, 72 (1989)

2. K.A. Zhukov, Ancient Russia. From Rurik to Batu (SPb., Piter, 2020) ISBN: 978-54461-1413-9

3. A.M. Valkovich, The Golden Age of the Russian Guard. 2 Volumes (2010) ISBN: 9785-93136-126-0

4. O.V. Sokolov, Napoleon's Army (M., Yauza, 2019) ISBN: 978-5-00155-126-3

5. I.E. Ulyanov, 1812 Russian Infantry on the Battlefield (Yauza, Eksmo, 2018) ISBN 978-5-699-29768-9

6. A.V. Kibovsky, 500 Unknown Soldiers (M., Russkiye Vityazi Fund, 2019) ISBN: 978-5-6041924-2-9

7. A.M. Novikov, Methodology of Artistic Activities (M., Egves Publishing, 2008) ISBN: 5-85449-064-1

8. Gallery of Paintings. Alexander Averyanov. Art of Painting, https://paintingart.ru/gallery/averyanov

9. S.P. Lomov, History and Methodological Theory of Teaching Drawing at Russian Schools (M., NII NEP, 2018)

10. Rigaud. Series «Plumet». Picture U12 «Neuchatel battalion 1807-1809-1812»

11. P.G. Alekhine, The Napoleonic Wars. Service Uniform of European Armies (M., Yauza, Eksmo, 2007) ISBN: 978-5-699-23191-1

12. Frederic Berjaud, Soldats Napoléoniens - Hors série 1, 21 (2003)

13. A. Pigeard, V. Bourgeot, Encyclopedie des Uniformes Napoleoniens, 1800-1815 (2003)

14. F.-G. Urtulle, Napoleon's Army. Soldiers and Service Uniforms of 1796-1815 (M., Eksmo, 2013) ISBN: 978-5-699-63670-9

15. Guye Alfred, Le Bataillon de Neuchâtel: dit des Canaris, au service de Napoléon, 1807-1814 (La Baconnière, 1964)

16. M. Oliver, Napoleon's Army. The Most Complete Guide to the Army of France and its Allies in 1799-1815 (M., AST, Astrel, 2005) ISBN: 5-17-026731-2 
17. Empire Styled Service Army Uniform. The Grand Army Infantry on the example of Neuchatel's Battalion: Study Guide. Part 2 (M., Editus, 2019) ISBN 978-5-00149-0708

18. S.P. Lomov, Painting. Guide Book. Edition 3, rev. and sup (M., AGAR, 2008) ISBN 978-5-89218-175-4 